\title{
5 (LIMA) NILAI BUDAYA KERJA KEMENTRIAN AGAMA (Analisis dari Injil Sinoptis)
}

\section{Ibelala Gea}

\begin{abstract}
This article aims to describe the results of research on the concept of the theory of five (5) values and culture of the Ministry of Religious how application analyzes according to the Synoptic Gospels. The study's findings pointed that the Synoptic Gospels (Matthew, Mark, and Luke) reported that before there was a theory about work culture values (integrity, professionalism, innovation, responsibility and exemplary), Jesus had taught and done it. Synoptic Gospels preach that Jesus had taught honesty both words and deeds (Matthew 5:37; Mark 12:13; Luke 16: 8). Professionalism got the attention of the teachings of Jesus (Luke 5:1-11) where skill is encouraged to be owned by everyone, but must remain to humble and prioritize the power of God in all of the things. Innovation is the attempt to always increase through a variety of creative and technology but progress must be obtained in true ways. Similarly, innovation should be based on the rules and God's will. In the Synoptic Gospel of preaching responsibility where everyone is expected to take responsibility for any deeds and actions, it is not only accountable to the people, but also for the God as the end of the responsibility to God as a receiver end (Matthew 25: 21-28).

While the value of the work culture model, the Gospels proclaim that Jesus taught that everyone must be an example in word and deed. Furthermore Matthew 20:28 and Mark 10:45, Jesus made a statement that He came to earth to serve and not be served.
\end{abstract}

Keywords: Work Culture and the Synoptic Gospels

\begin{abstract}
Abstrak
Artikel ini bertujuan untuk mendeskripsikan hasil penelitian tentang konsep teori 5 (lima) nilai budaya kerja Kementerian Agama dan bagaimana analisis aplikasinya menurut Injil Sinoptis. Temuan penelitian menunjuk bahwa Injil Sinoptis (Matius, Markus, dan Lukas) memberitakan bahwa jauh sebelum ada teori nilai budaya kerja (integritas, profesionalitas, inovasi, tanggungjawab dan keteladanan), Yesus telah mengajarkan dan melakukannya. Injil sinoptis memberitakan bahwa Yesus telah mengajarkan kejujuran baik perkataan dan perbuatan (Matius 5:37; Markus 12:13; Lukas 16:8). Profesionalitas mendapat perhatian dari pengajaran Yesus (Lukas 5:1-11) dimana keahlian sangat didorong untuk dimiliki oleh semua orang, namun harus tetap rendah hati dan mengutamakan kuasa Tuhan dalam segala hal. Inovasi adalah usaha untuk selalu mengalami peningkatan melalui berbagai kreasi dan teknologi, namun kemajuan harus didapat dengan cara-cara yang benar. Demikian inovasi sebaiknya didasarkan pada peraturan dan kehendak Tuhan. Di dalam Inji Sinoptis memberitakan tentang tanggungjawab. Dimana setiap orang diharapkan bertanggungjawab pada setiap perbuatan dan tindakannya, bukan hanya dipertanggungjawabkan kepada manusia, tetapi juga kepada Allah sebagai penerima tanggungjawab akhir (Matius 25:21-28).
\end{abstract}


Sedangkan nilai budaya kerja keteladanan, kitab Injil memberitakan bahwa Yesus mengajarkan supaya setiap orang harus menjadi teladan dalam perkataan dan perbuatan. Lebih jauh Injil Matius 20:28 dan markus 10:45, bahwa Yesus telah membuat pernyataan bahwa Ia datang ke dunia untuk melayani dan bukan dilayani.

Kata Kunci: Budaya Kerja dan Injil Sinoptis

\section{PENDAHULUAN}

Sekolah Tinggi agama Kristen Protestan Negeri Tarutung (STAKPN) adalah perguruan tinggi berdasarkan Surat Keputusan Presiden Republik Indonesia No. 19 tanggal 29 Maret 1999, itu berarti STAKPN Tarutung bagian dari Satuan Kerja (satker) Kementerian Agama yang jumlahnya cukup besar kurang lebih 4.484 satker. Karena itu secara formal STAKPN Tarutung adalah binaan Kementerian Agama yang senantiasa berpedoman pada nilai-nilai budaya kerja Kementerian Agama dalam melaksanakan tugasnya. Pada hakekatnya tidak terkecuali seluruh satuan unit kerja yang berada di lingkungan Kementerian Agama, baik sekolah atau perguruan tinggi negeri atau swasta, dan unit kerja lainnya, semestinya memahami dan mempedomani peraturan Kementerian Agama inklud didalamnya nilai-nilai budaya kerja. Perlu direnungkan ulang apakah seluruh para pimpinan, pegawai/karyawan dilingkungan Kementerian Agama telah memahami nilai-nilai budaya kerja dimaksud, serta bagaimana perspektif kitab injil terhadap nilai-nilai budaya tersebut. Direktur Jenderal Bimas Kristen Kemenag RI, Oditta Hutabarat dalam pidatonya ketika memberi bimbingan dan arahan pada acara wisuda STAKPN Tarutung 16 Maret 2016 yang ke 15 menyebutkan bahwa ada 5 (lima) nilai budaya kerja Kementerian Agama yaitu:

1. Integritas

2. Profesionalitas

3. Inovatif

4. Tanggung jawab

5. Keteladanan ${ }^{1}$

Menurut Kamus Umum Bahasa Indonesia, secara leterlet Integritas artinya: "kebulatan, keutuhan"2. Dapat penulis tambahkan, bahwa integritas berarti tidak ada kepalsuan, melainkan transparansi dapat diketahui baik lahir 
maupun batin secara utuh, berbicara apa adanya karena berkomitmen mau hidup dan berpegang pada kejujuran. Oleh sebab itu bekerja dengan mengutamakan integritas sama dengan mengedepankan kejujuran, ketulusan dan keiklasan. Di dunia ini mudah menemukan pemimpin dan para pegawai yang memiliki tingkat intelektual yang tinggi dan manajerial yang handal, tetapi menemukan pemimpin yang berintegritas sangatlah sulit. Karena itu perlu dicari formula kriteria persyaratan pada perekrutan para pegawai dan pemimpin yaitu dengan mengutamakan orang-orang yang memiliki kepribadian yang berintegritas. Sedangkan faktor kompetensi seperti kemampuan akademik, dan sebagainya sebagai kategori kedua dan seterusnya. Nilai-nilai budaya kerja dari aspek integritas adalah bahwa seluruh aparatur baik yang memiliki kompetensi sebagai pemimpin dan yang dipimpin bertekad bulat secara utuh melakukan yang terbaik dan benar dalam bekerja melayani masyarakat, berkomitmen dan memiliki niat untuk tidak melanggar sumpah atau janji, baik sebagai pimpinan, pegawai dan karyawan, berusaha menolak segala bentuk rekayasa dan manipulasi, menolak atau tidak menerima segala pemberian dalam bentuk apapun kecuali jika ada ketentuan yang mengatur hal itu.

$\underline{\text { Integritas }}$ adalah kata yang sering terdengar untuk mengukur mutu dan kualitas para pemimpin dan calon pemimpin. Namun terkadang sulit mengukur dan memberi penilaian yang yang objektif dan valid untuk memilih para pemimpin, karena kualitas mereka hampir tidak dapat dibedakan atau beda tipis dari aspek pengetahuan, kompetensi, visi dan misi. Namun jika ada aspek penilaian lain dari segi integritas yang meliputi karakter, kejujuran, ketulusan dan keiklasan kemungkinan dapat terlihat perbedaan yang hakiki. Persoalan adalah mengungkap integritas seseorang tidaklah gampang, sehingga di dunia yang penuh sandiwara ini, setiap orang seakan dengan mudahnya menutupi kebobrokannya dengan bungkusan integritas yang semu.

Berkarya dengan penuh disiplin, serta memiliki seperangkat kompetensi, ketepatan waktu secara efektif dan efesien dan memberikan hasil pekerjaan yang terbaik dapat disebut sebagai kriteria profesionalitas. Para ahli managemen mendeskripsikan bahwa perencanaan menjadi kata kunci dalam segala pekerjaan. 
Inspektorat Jenderal Kementerian Agama menuliskan: "Rencana kinerja/Renja/merupakan pedoman bagi para pejabat dan pelaksana dalam melaksanakan tugas. Renstra (rencana dan strategi) perlu dipahami oleh seluruh unsur satuan kerja agar pelaksanaan kegiatan dan pencapaian sasaran dapat lebih terkoordinasi dan sinergis"3. Artinya orang yang bekerja secara profesional harus mengawalinya dengan perencanaan yang meliputi uraian, sasaran, indikator, target dan capaian. Pada perguruan tinggi, dosen tugas pokoknya adalah melaksanakan Tri Dharma Perguruan Tinggi yaitu, mengajar, meneliti dan mengabdi. Untuk melaksanakan tugas secara profesional, diawali dengan perencanaan, dilanjutkan dengan pelaksanaan, evaluasi dan pelaporan kepada atasannya. Terkadang telah dilakukan perencanaan perkuliahan (mengajar), penelitian dan pengabdian, tetapi bagaimana pelaksanaannya; karena itu pelaporan yang rutin perlu dilakukan yang dimuat dalam BKD (Beban Kinerja Dosen). Sekaitan dengan profesionalitas para dosen dalam melakukan Tri Dharma Perguruan Tinggi, Ibelala Gea, berpendapat: "Untuk menjamin pelaksanaan tugas sesuai dengan kriteria yang ditetapkan maka setiap dosen perlu membuat laporan atau melengkapi data-data, dan laporan tersebut didokumentasikan untuk kepentingan perguruan tinggi dan kepentingan dosen itu sendiri". ${ }^{4}$

Oleh sebab itu bekerja secara profesionalitas ditandai dengan melaksanakan pekerjaan sesuai jabatan masing-masing, menyelesaikan tugas dengan tepat waktu dan siap menerima reward dan punishment sesuai peraturan. Para pimpinan, pegawai dan karyawan di lingkungan Kementerian Agama, bertekad ber-Inovasi. Kamus Umum Bahasa Indonesia, mengartikan kata inovasi adalah pembaharuan ${ }^{5}$. Artinya dalam bekerja perlu melakukan pembaharuan, menyempurnakan, meningkatkan nilai mutu hasil kerja. Para pegawai, termasuk para tenaga pengajar berupaya berkreasi, tidak puas dengan pelayanan biasa-biasa, seperti berusaha memanfaatkan teknologi informasi dalam pelayanan. Para guru dan dosen menggunakan komputer, infocus dan fasilitas lainnya pada saat melayani peserta didik, mengembangkan bahan ajar dari kurikulum dan silabus serta mengajar dengan multi metoda yang bervariasi. 
Sebagai Pegawai Negeri Sipil dan Aparatur Negara mengembangkan nilainilai tanggungjawab dalam bekerja. Indikatornya adalah bekerja sepenuh hati, mengerjakan sesuatu dengan tuntas dan konsekuen. Ciri-ciri pegawai yang bertanggungjawab memiliki komitmen dan ketetapan hati dalam mengerjakannya. Segala masalah yang dijumpai selalu ada usaha untuk mengatasinya. Jikapun ada kekeliruan atau kesalahan dalam mengerjakan pekerjaan senantiasa berjiwa satria berani mengakui kesalahan dan berusaha untuk memperbaiki kesalahan. Artinya tidak melemparkan kesalahan kepada orang lain, misalnya menyalahkan bawahan atau atasan, apalagi tidak menyalahkan situasi atau alat yang digunakan sebagai sarana dalam bekerja. Bersedia mengerjakan yang diberikan oleh atasan atau yang sesuai dengan job description, serta tidak menyalahkan wewenang dan tanggung jawab.

Keteladanan, dijadikan sebagai gaya hidup. Kehadiran di kantor bukan hanya karena ada aturan yang bersifat memaksa. Bukan hanya takut kepada atasan dan peraturan yang ada, melainkan kehadiran berkantor untuk bekerja karena telah menjadi kebiasaan atau gaya hidup. Absen manual dan elektronik hanyalah sebagai media administrasi yang berfungsi mengatur jam kerja para pegawai bukan sesuatu yang ditakuti.

Seorang pegawai atau Abdi Negara berusaha memberi pelayanan yang prima bagi masyarakat. Sebagai atasan tidak bersifat diskriminatif, tidak membeda-bedakan seluruh para pegawai. Secara alamiah pasti ada para pegawai yang menyenangkan dan sebaliknya, yang taat displin dan sebaliknya. Namun mereka semua adalah berhak mendapatkan keteladanan dari atasan mereka. Atasan berperan tetap memberi keteladanan kepada mereka dalam perbuatan dan perkataan. Keramahan menjadi salah satu ciri khas pengajaran keteladanan yang prima.

Injil Sinoptis adalah kitab pertama dari Alkitab Perjanjian Baru, yang menurut tradisi hampir seluruh isinya adalah berasal dari perkataan dan perbuatan Yesus. Perkataan sinoptis dari bahasa Yunani $\boldsymbol{\sigma v \boldsymbol { v }}$ (syn artinya bersama) dan $\boldsymbol{o Y} \boldsymbol{\varsigma}$ (opsis artinya melihat). Karena itu sinoptis dapat berarti memiliki pandangan yang sama terhadap sesuatu. Injil Sinoptis adalah terdiri dari Matius, Markus dan 
Lukas. Ketiga kitab injil ini "memiliki kesamaan dalam mengungkapkan perkataan dan perbuatan Yesus Kristus". ${ }^{6}$ Kesamaan itu ada yang persis sama, namun tidak berarti kata, kalimat persis sama. Artinya bahwa, substansi isi tulisan dan pemberitaan berbeda, tetapi materi yang diberitakan adalah sama. Adapun penulis injil Matius, Markus dan Lukas yang materinya sama antara lain:

1. Yesus memanggil keduabelas Rasul (Matius 10:1-5; Markus 3:13-19; Lukas 5:1216).

2. Yesus menyembuhkan yang sakit kusta (Matius 8:1-4; Markus 1:40-45; Lukas 5:12-16).

3. Yesus menyembuhkan ibu mertua Petrus dan orang-orang lain (Matius 8:14-17, Markus 1-29-34; Lukas 4:38-41).

4. Yesus menyembuhkan orang lumpuh (Matius 9:1-8; Markus 2:1-12; Lukas 5:1726).

5. Yesus membangkitkan anak kepala rumah ibadah yang sudah mati (Matius 9:1826; Markus 5:21-43; Lukas 8:40-56)

6. Yesus meredakan badai dan angin ribut (Matius 8:23-27; Markus 4:35-41; Lukas 8:22-25).

7. Yesus memberi makan 5000 orang (Matius 14:13-21; Markus 6:30-44; Lukas 9:10-17).

8. Yesus memberitakan tentang penderitaan-Nya (Matius 16: 91-98; Markus 8:319:11; Lukas 9:22-27).

9. Yesus memberitakan kembali penderitaanNya (Matius 17:22-23; Markus 9:30-33; Lukas 9:43-45).

10. Yesus dimuliakan di atas gunung (Matius 17:1-13; Markus 9:2-13; Lukas 9:2836).

11. Yesus menyembuhkan pemuda yang sakit ayan ( Matius 17:14-21; Markus 9:1424; Lukas 9:37-43).

12. Yesus mengajar tentang siapa yang terbesar dalam kerajaan sorga (Matius 18:111; Markus 9:33-37; Lukas 9:46-48).

13. Yesus memberitakan kembali penderitan-Nya (Matius 20:17-19; Markus 10:3234; Lukas 18:31-34).

14. Yesus menyembuhkan dua orang buta (Matius 20:29-34; Markus 10:46-52; Lukas 18:35-43).

15. Yesus memberi perumpamaan tentang penggarap-penggarap kebun anggur (Matius 21:33-46; Markus 12:1-21; Lukas 20:9-19).

16. Yesus mengajarkan tentang membayar pajak (Matius 22:15-22; Markus 12:13-17; Lukas 20:20-26).

17. Yesus mengajarkan hukum yang utama dan terutama (Matius 22:34-40; Markus 12:28-34; Lukas 10:25-28).

18. Yesus melaksanakan perjamuan kudus malam dengan murid-muridNya (Matius 26:26-29; Markus 14:22-25; Lukas 22:15-20).

19. Yesus berdoa di taman Getsemane (Matius 26:36-45; Markus 14:32-42; Lukas 22:39-46). 
Pengertian Injil secara sederhana dapat dilihat dari beberapa referensi antara lain:

a. Menurut Kamus Alkitab; Injil kata Yunani: "Evanggelion" yang berarti kabar gembira, berita baik, kedatangan Yesus Kristus dan memulainya pemerintahan Allah di dunia ini merupakan inti Injil yang harus diberitakan kemana-mana (Matius 24:24) ${ }^{7}$

b. Menurut Ensiklopedi Alkitab masa kini; Injil (Yunani Evanggelion, kabar baik). Dalam kesusastraan klasik, kata ini mengacu kepada pahala yang diberitakan untuk berita baik ${ }^{8}$

c. Menurut Ensiklopedi Alkitab Praktis, Injil berarti "kabar baik dari Allah yang mengutus Yesus Kristus untuk menjadi Tuhan dan Juruselamat manusia ( I Tesalonika 2:9). Kata itu berasal dari bahasa Yunani yang secara harafiah berarti kabar baik". 9

Sedangkan menurut Rasul Paulus dalam surat Roma 1:16-17 dikatakan "Sebab aku mempunyai keyakinan yang kokoh dalam Injil, karena Injil adalah kekuatan Allah yang menyelamatkan setiap orang yang percaya, pertama-tama orang Yahudi, tetapi juga orang Yunani. Sebab di dalamnya nyata kebenaran Allah, yang bertolak dari iman dan memimpin kepada iman, seperti ada tertulis: 'Orang benar akan hidup oleh iman'”. Dari nats Roma 1 :16-17; dapat dikatakan bahwa Paulus mengungkapkan dua arti yang menjadi makna dari Injil.

Pertama : di dalam Injil berisi kabar baik sebagai kekuatan dan kekuasaan Allah. Kekuatan dan kuasa Illahi tersebut terlihat pada kekuatan-Nya yang telah mengubah dunia didalam Kristus yang telah mengalahkan kuasa dosa dan maut serta dibenarkan orang berdosa (Roma 4:25). Dengan sudah dikalahkan-Nya dosa dan maut, maka setiap orang percaya dianugrahkan kehidupan yang baru (Roma 7:1-4). Kini seluruh umat manusia seharusnya bersyukur dan bermegah telah diampuni dosa dan pelanggarannya (Kolose 1:13). Maka manusia yang selama ini telah menjadi seteru Allah, kini sudah berdamai dengan Allah dan hidup yang sekarang selalu diwarnai oleh hidup damai sejahtera Allah (Roma $5: 1)$.

Kedua : ditandaskan Paulus bahwa anugerah keselamatan tidak dibatasi, semua orang baik Yahudi maupun Yunani samasama dikasihi dan diselamatkan. Keselamatan adalah lawan dari hukuman dan murka Allah (Roma 1:18) yang membawa kepada kematian dan kebinasaan. Tetapi oleh berita Injil manusia yang percaya diselamatkan (Roma 5:9; 
10:10), karena itu Injil harus diberitakan kepada seluruh bangsa-bangsa (Matius 28:19-20). Rasul Paulus menyatakan : karena jika aku memberitakan Injil aku tidak punya alasan untuk memegahkan diri. Sebab itu adalah keharusan bagiku. Celakalah aku, jika aku tidak memberitakan Injil (I Korintus 9:16).

\section{Tujuan Penelitian}

Penelitian ini bertujuan untuk menjelaskan nilai -nilai budaya kerja Kementerian Agama secara teoritis, serta menjelaskan bagaimana prespektif kitab Injil Sinoptis, terhadap nilai- nilai budaya kerja dimaksud.

\section{Metode Penelitian}

Metode penelitian artikel ini adalah menggunakan pendekatan kajian pustaka (Library Research), dengan cara membandingkan sejumlah referensi yang berhubungan dengan nilai budaya kerja Kementerian Agama (integritas, profesionalisme, inovasi, tanggungjawab dan keteladanan). Kemudian melihat dari perspektif pandangan Kitab Injil Sinoptis, yaitu Injil Matius, Markus dan Lukas.

\section{Analisis Injil Sinoptis terhadap Nilai Budaya Kerja Kementerian Agama}

Setelah menguraikan berbagai teori tentang ke 5 (lima) nilai budaya kerja Kementerian Agama, selanjutnya peneliti mengungkapkan bagaimana pandangan Injil Sinoptis terhadap nilai-nilai budaya dimaksud.

\section{Injil dengan integritas}

Jika dipahami bahwa integritas mengandung pengertian Integrity yang berarti: "kejujuran, ketulusan hati, dan keutuhan"10, maka kitab Injil Sinoptis secara representatif mengartikan integritas adalah apa yang dikatakan dan dilakukan oleh Yesus dan ditulis dalam Injil diantaranya adalah:

a. Matius 5:37 i: Jika ya, hendaklah kamu katakan: ya, jika tidak, hendaklah kamu katakan: tidak. Apa yang lebih dari pada itu berasal dari si jahat. Perkataan Yesus ini 
diterjemahkan dari Alkitab berbahasa Yunani yang

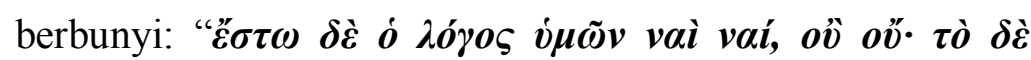

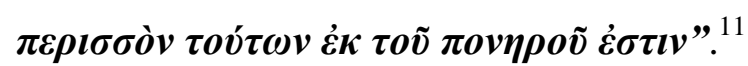

Perkataan Yesus itu hendak mengatakan bahwa karakter orang yang percaya kepada Tuhan tidak boleh berliku-liku, harus hidup jujur dalam segala hal. Ya jika ya, tidak kalu tidak, lebih dari itu berasal dari si jahat (But let your 'yes' be' yes, and your no, no. For whatever is more than these in from the evil one”). Para ahli tafsir mengartikan Matius 5:37 adalah "kata-kata seseorang haruslah dapat dipercaya tanpa upacara tambahan untuk membuat kata-kata itu dianggap sah. Si jahat dapat juga berarti umat manusia yang berdosa. ${ }^{12}$ Kebiasaan orang- orang Yahudi dimasa Yesus suka bersumpah.Sumpah terkadang bermuatan palsu, karena orang Yahudi takut menyebut nama Allah maka mereka gunakan nama lain seperti demi Kota Jerusalem atau Taurat, guna meyakinkan orang lain atau hakim . Yesus memberi pengajaran yang bersifat paranesis supaya tidak berkata palsu, sebab kepalsuan dan kebohongan bersumber dari setan.

Penulis teringat persaingan yang sangat ketat pada pemilihan presiden Amerika Serikat yakni George Bush dengan Richard Nixon pada tahun tujuh puluan. Namun Nixon mengakui keunggulan Bush sebagaimana dilaporkan oleh Stephen L. Carter: dalam tahun 1972, tepat seminggu sebelum pemilihan kembali Richard Nixon secara besar-besaran, New York Times, yang telah mendukung lawannya, menerbitkan suatu karangan yang melihat jauh kedepan dengan mengatakan bahwa "keutamaan yang paling penting dalam perpolitikan ialah kejujuran"13. Di situ Nixon mengakui keunggulan lawannya George Bush. Dengan mengakui keunggulan lawan dengan dasar berpikir yang jujur, maka sesungguhnya telah ditunjukkan Integritas. Perkataan bersumpah palsu pada umumnya bertujuan mengalahkan lawan dan membernarkan diri sendiri, namun perbuatan itu merugikan diri sendiri yaitu tidak jujur.

Dunia ini adalah tempat persaingan dalam berbagai hal, baik di bidang bisnis, politik, ilmu pengetahuan dan teknologi, namun seharusnya nilai-nilai kejujuran menjadi prioritas. Integritas yang hakiki ditemukan dalam diri dan pelayanan Yesus sebagaimana diberitakan dalam kitab Injil Sinoptis. 
b. Markus 12:14, yang berbunyi:“'Orang-orang itu datang dan berkata kepada-Nya: Guru, kami tahu, Engkau adalah seorang yang jujur, dan Engkau tidak takut kepada siapapun juga, sebab Engkau tidak mencari muka, melainkan dengan jujur mengajar jalan Allah dengan segala kejujuran'. Apakah diperbolehkan membayar pajak kepada Kaisar atau tidak? Haruskah kami bayar atau tidak?".

Kata-kata ini dalam terjemahan bahasa Yunani berbunyi demikian: $\boldsymbol{\kappa} \boldsymbol{\alpha} \boldsymbol{\imath}$

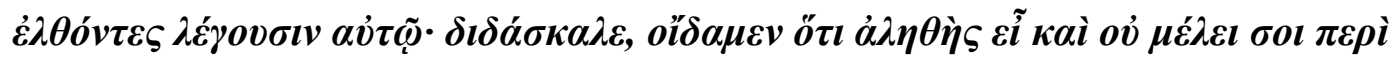

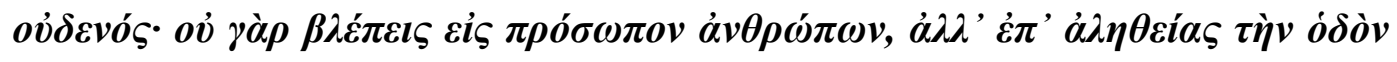

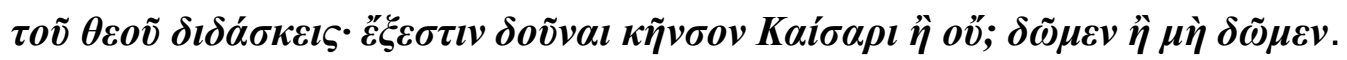

Pertanyaan orang yang menjumpai Yesus pada cerita dalam Markus 12:14 adalah pertanyaan yang mengandung jebakan dari para ahli Taurat dari kalangan Farisi dan kelompok Herodian (Markus 12:13), dengan tujuan diharapkan Yesus salah menjawab bahwa tidak harus membayar pajak kepada Kaisar. Maka jikalau Yesus mengatakan tidak wajib membayar pajak kepada Kaisar, maka orang Farisi bersama orang Herodian melaporkan Yesus kepada Kaisar Romawi sebagai anti pemerintahan Kaisar. Namun menarik, jika dianalis pertanyaan lawan-lawan Yesus, maka di satu pihak mereka mengakui dan memuji kejujuran Yesus, namun di lain pihak bukan pengakuan positif melainkan sebagai kiasan saja. Ternyata Yesus tidak terpancing dari sanjungan dan pujian mereka itu. Yesus buktikan ya kalau ya dan tidak kalau tidak, dengan mengatakan pada ayat 17. Lalu kata Yesus kepada mereka : "Berikanlah kepada Kaisar apa yang wajib kamu berikan kepada Kaisar dan kepada Allah apa yang wajib kamu berikan kepada Allah". Mereka sangat heran mendengar Dia. Secara Teologis dalam pengajaran Yesus terlihat dua kewajiban yaitu, kepada Kaisar dan kepada Allah, dengan melakukan kedua kewajiban itu telah ditunjukan pula nilai Integritas.

c. Lukas 16:8 yang berbunyi: "Lalu tuan itu memuji bendahara yang tidak jujur itu, karena ia telah bertindak dengan cerdik. Sebab anak-anak dunia ini lebih cerdik terhadap sesamanya dari pada anak-anak terang”. 


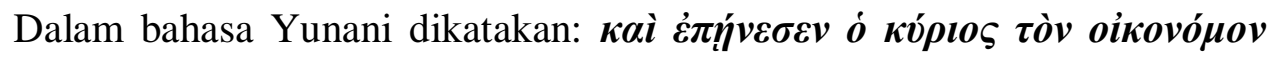

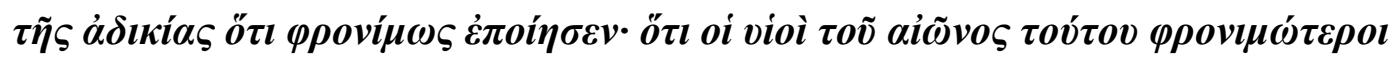

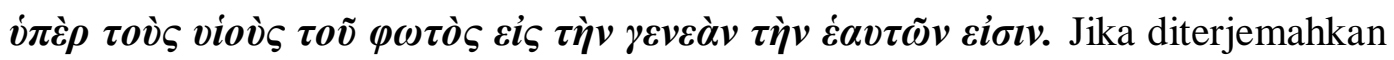
dalam bahasa Inggris adalah demikian: "so the master commended the un just steward because he had dealt shrewdly. For the sons of this world are more shrewd in their generation than the sons of light".

Lukas 16 adalah bentuk perumpamaan tentang bendahara yang tidak jujur. Jika hanya sepintas dibaca tidak dianalisis makna perumpamaan ayat 8 ini, dapat dikatakan Yesus seolah-olah memuji ketidakjujuran bendahara yang telah salah urus perusahaan tuannya itu. Tetapi hasil penafsiran menjelaskan bahwa: "penata usaha itu sendiri tidak dipuji, tetapi dengan jelas disebutkan 'tidak baik' atau 'lalim', yaitu pintar busuk dan tidak jujur terhadap tuannya, apa yang dipuji tuannya itu hanya kecerdikannya atau kepintarannya dan kegiatannya dalam mengurus masa depannya". ${ }^{14}$

Bendahara dalam Lukas 16 ayat 8 ini, cerdik atau pintar tetapi tidak baik karena hanya menggunakan kesempatan mempersiapkan masa depannya, tanpa perduli kerugian tuannya. Di dunia ini banyak orang yang memiliki kecerdasan intelektual dalam tanda petik, tetapi lemah atau tidak memiliki integritas yaitu kejujuran. Sebab itu cerdas secara intelektual tetapi lemah secara spiritual sama dengan tidak memiliki integritas.

Oleh sebab itu kitab Injil menjelaskan tidak mengabaikan kecerdasan intelektual, melainkan mengutamakan kejujuran atau integritas. Sebagai peringatan bagi orang percaya disampaikan oleh William Barclay; dalam ayat 8 , bahwa anak-anak dunia ini lebih bijaksana dalam generasi mereka dari anak-anak terang. Hal ini berarti bahwa, hanya jika orang kristen ingin sungguh-sungguh dan jujur dalam upaya mencapai kebaikan sama seperti bersungguh-sungguh orang dunia itu dalam hal mencari uang dan kesejahteraan, maka ia akan menjadi orang yang jauh lebih baik ${ }^{15}$. Karena itu dapat dikatakan bahwa pesan Teologis dari perumpamaan itu, hendak memberi motivasi kepada anak-anak Tuhan atau orang Kristen suapaya bekerja keras dan cerdas melakukan kebaikan yang mendatangkan kesejahteraan bagi diri sendiri dan orang lain. Semangat orang- 
orang dunia ini yang begitu semangat kerja keras mempersiapkan masa depanya, maka anak-anak Tuhan atau orang Kristen, seharusnya lebih bersemangat dalam kerja keras dan cerdas, dengan mengedepankan integritas, untuk melakukan kebaikan yang mendatangkan kesejahteraan bagi semua orang. Perbuatan semacam itulah yang dikategorikan telah menemukan makna hidup yang berintegritas.

\section{Injil dengan Profesionalitas}

Profesionalitas berhubungan dengan keahlian dalam berkaya.Pekerjaan yang didasarkan pada profesionalitas adalah minimal diawali dengan perencanaan yang baik, dilanjutkan dengan pelaksanaan, diakhiri dengan hasil dan pelaporan yang akuntabel dan terukur. Bekerja harus dengan sungguh-sungguh bekerja keras dan cerdas. Banyak pekerjaan yang dikerjakan tetapi dengan modal hanya kerja keras tanpa kecerdasan hasilnya pasti ada, tetapi kemungkinan kurang memuaskan. Bekerja sungguh-sungguh atau bekerja keras disertai kecerdasan atau keahlian hasilnya efektif, efisien, dan memuaskan. Namun cerita dalam Injil Lukas 5:1-11, yang isinya mengungkap strategi Yesus merekrut murid-muridNya. Perlu diketahui bahwa salah seorang murid-Nya bernama Simon Petrus. Ia memiliki keahlian sebagai nelayan yang dari pengalamannya dapat dikategorikan dia adalah seorang nelayan yang Profesional. Sejak kecil Petrus telah berprofesi sebagai nelayan penangkap ikan, terutama di Danau Galilea. Akan tetapi pada Lukas 5:4-5 berbunyi: Setelah selesai berbicara, Ia berkata kepada Simon: "Bertolaklah ke tempat yang dalam dan tebarkanlah jalamu untuk menangkap ikan.". Simon menjawab: "Guru, telah sepanjang malam kami bekerja keras dan kami tidak menangkap apa-apa, tetapi karena Engkau menyuruhnya, aku akan menebarkan jala juga."

Dialog antara Yesus sebagai guru dengan Simon Petrus sebagai murid

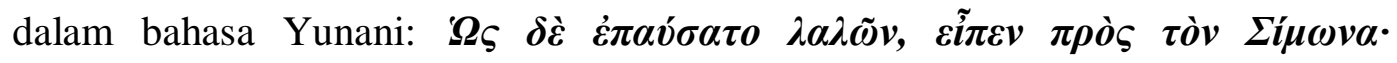

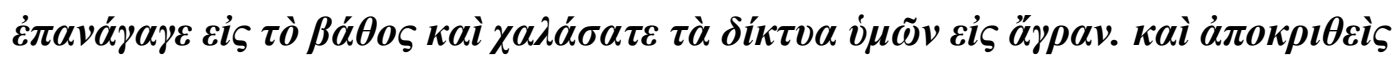

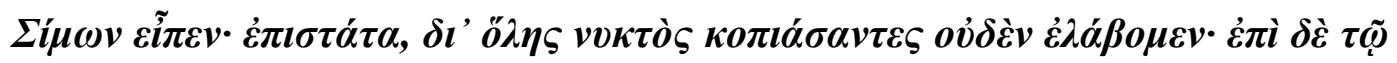

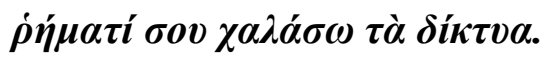


Sebagai nelayan yang profesional, Simon Petrus ternyata dapat gagal. Sebab para penafsiran mengatakan: "waktu yang paling baik menangkap ikan ialah malam hari di air yang dalam, pada waktu siang mereka menangkap ikan di tempat dangkal". ${ }^{16}$

Sementara Petrus sebagai ahli penagkap ikan telah bekerja keras semalaman tanpa ada hasil. Tetapi Yesus menyuruh menangkap ikan justru pada siang hari, ternyata hasilnya luar biasa, pada Lukas 5:6, dikatakan: Dan setelah mereka melakukannya, mereka menangkap sejumlah besar ikan, sehingga jala mereka mulai koyak. (and then they had done this, they caught a great number of fish, and their net was breaking).

Dalam melakukan pekerjaan, meskipun telah memiliki sejumlah keahlian yang profesional, mungkin secara kompetensi akademik telah memenuhi persyaratan dan bahkan seperangkat kompetensi lainnya sudah dimiliki. Namun kitab Injil Sinoptis mengungkap tabir keajaiban. Tabir keajaiban itu melampaui batas keprofesionalitasan Simon Petrus sebagai nelayan ahli. Dimana Yesus menyuruh Simon Petrus menjala ikan bukan pada malam hari tetapi pada siang hari. Perintah Yesus itu adalah kontradiktif dengan keahlian Simon Petrus. Telihat pada jawaban Petrus pada ayat 5, simon menjawab : Guru, telah sepanjang malam kami bekerja keras, dan kami tidak menangkap apa-apa , tetapi karena Engkau menyuruhnya aku akan menebarkan jala juga.

Dari hasil analisis pesan Teologis dari Injil Sinoptis, ternyata pengajaran Yesus meniadakan segala perangkat kompetensi yang menciptakan keahlian yang disebut profesionalitas, melainkan harus meyakini bahwa masih ada kekuatan supranatural yang melampaui batas ke ilmuan manusia yaitu kekuasaan Tuhan. Kekuasaan Tuhan itu terkadang terlupakan oleh keasyikan dengan segala macam keilmuan dunia sekuler ini. Maka sebaiknya harus sama-sama dicari yaitu mencari ilmu dengan segala keahliannya secara benar bukan hanya sekedar gelar atau embel-embel, dan yang yang tidak boleh diabaikan adalah carilah Tuhan dan Kuasa-Nya yang ajaib itu. Para ahli managemen mengungkap tabir persyaratan keprofesionalan, diantaranya sebagaimana pendapat Joel E. Roes dalam buku Joko Widodo: "Kriteria profesi mencakup: 'knowlegde, competent application, 
social responsibility, self control, community sanetian'. Knowledge berarti: suatu jabatan atau okupasi tersebut mensyaratkan suatu pengetahuan yang tinggi dan diperoleh melalui pendidikan tinggi dengan waktu relatif lama. Competence application untuk melaksanakan tugas pekerjaan profesi tadi diperlukan suatu kecakapan dan keahlian tinggi tertentu. Orang-orang yang memiliki keahlian dan kecakapan tinggi disebut profesional. Social responsibility artinya kecakapan dan keahlian tadi diabdikan ke maslahat orang banyak atau untuk kesejahteraan masyarakat. Self-control, yang bisa melakukan kontrol perbuatan orang-orang profesional hanya orang-orang yang seprofesi. Community sanetian, sangsi terhadap orang-orang profesional ketika melakukan mal praktik adalah dari masyarakat mereka. Misalnya IWI (Ikatan Wartawan Indonesia)" ${ }^{17}$ Kitab Inijil tidak mengabaikan profesionalitas, namun diatas semuanya itu adalah mengandalkan Kuasa-Nya.

\section{Injil dan Inovasi}

Inovasi dapat diartikan sebagai sikap manusia yang selalu ingin mengalami kemajuan (move on) di segala aktivitasnya. Keinginan untuk tidak ketinggalan meskipun menumpai sejumlah tantangan dan rintangan, namun dengan modal kesabaran, kerendahan hati, dan keyakinan, dapat mencapai citacita.

Injil Matius 15: 21-28, memberitakan seorang perempuan Kanaan, yang dalam injil Markus 7: 25 menyebutnya orang Siro-Fenisia. Statusnya tidak termasuk umat Allah seperti Israel, sehingga dapat dikatakan perempuan itu seorang kafir. Namun ia datang dan memohon kepada Yesus agar berkenan menyembuhkan anaknya yang sedang sakit dirasuki setan, dan sangat menderita. Ternyata Yesus menjawabnya bahwa: Aku diutus hanya kepada domba-domba yang hilang yang hilang dari umat Israel ( Maitus 15: 24 ).

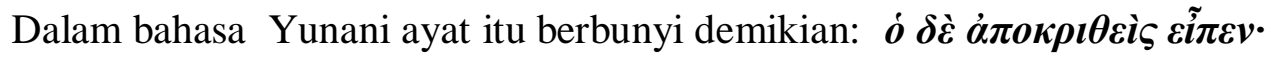

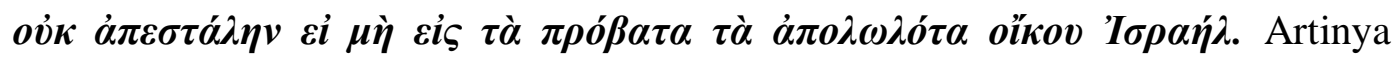
perempuan itu belum layak mendapat pelayanan dari Yesus. Namun di Matius 15: 25 dikatakan: "Tetapi perempuan itu mendekat dan menyembah Dia, sambil 
berkata: 'Tuhan, tolonglah aku"'. Seorang perempuan kafir terus maju dan memohon belas kasihan, kembali mamanggil Yesus adalah Tuhan. Namun Yesus menjawabnya pada Matius 15: 26, tidak patut mengambil roti yang disediakan bagi anak- anak dan melemparkan kepada anjing.

Perkataan Yesus itu cukup keras. Karena perempuan itu digolongkan pada kelompok hewan. Sementara Israel sebagai anak-anak Allah atau umat pilihan. Akan tetapi perempuan Kanaan itu memohon terus belas kasihan dari Yesus. Ia tidak menjadi marah atas perbedaan yang dibuat di antara bangsa Israel dan bangsa- bangsa kafir. Dengan rendah hati ia menerima penetapan Allah, kalau Allah memberi perhatian khusus kepada Israel sebagi bangsa terpilih, ia mau menerima bahwa ia tidak layak menerima pertolongan sebagai seorang yang tidak masuk bangsa Israel ${ }^{18}$.

Inovasi perempuan kanaan itu mendapat pujian dari Yesus, di mana (Matius 15: 27), kata perempuan itu benar Tuhan, namun anjing itu makan remah- remah yang jatuh dari meja tuannya. Maka Yesus menjawabnya: "Hai ibu, besar imanmu, maka jadilah kepadamu seperti yang kau kehendaki”. Dan seketika itu juga anaknya sembuh (The Jesus answered an said to her, o. woman, great is your faith. Let it led from that very hour, (Matius 15: 28)).

Sikap inovatif yang standar adalah tidak cepat putus asa dalam segala hal, berusaha mencari solusi dengan berbagai cara untuk menyelesaikan dan mengatasi masalah namun bukan menghalalkan segala cara. Pegawai/karyawan yang inovatif dapat melakukan berbagai terobosan sepanjang tidak bertentangan dengan peraturan dan kehendak Tuhan.Terkadang ada inovasi yang merusak orang lain seperti merakit bom, membuat senjata tanpa izin, membentuk organisasi yang ideologinya bertentangan dengan Pancasila dan NKRI walaupun mengatas namakan nama Allah. Pelayanan yang inovatif bersifat efektif, efisien, tidak merusak diri sendiri dan orang lain serta hasilnya memuaskan para pelanggan.

\section{Injil dan Tanggungjawab}


Setiap orang, sekecil apapun pekerjaannya dan serendah apapun jabatannya, harus mempertanggungjawabkan hasil pekerjaannya, kepada manusia dan kepada Allah yang Maha Kuasa dan yang Maha Tahu.

Sebagai pegawai/karyawan diharapkan mempertanggungjawabkan hasil kerjanya kepada atasannya. Demikian juga atasan atau para pemimpin mempertanggungjawabkan pekerjaan mereka kepada pejabat yang lebih tinggi di atasnya, dan pertanggungjawaban akhir adalah kepada Allah pencipta dan pemilik alam semesta. Salah satu contoh bagaimana orang mempertanggung jawabkan pekerjaan sebagaiamana dikisahkan dalam injil Maitus 25: 21 - 28, di mana Yesus mengajarkan bagaimana kerajaan sorga dan bagaimana supaya setiap orang dapat masuk bersama dengan Dia kedalamnya. Yesus menggunakan sebuah perumpamaan seorang tuan atau majikan yang hendak bepergian ke luar negeri. Kemudian majikan itu memanggil para pegawai atau hamba-hambanya dan membagikan kepada mereka hartanya yang diungkapkannya dalam bentuk talenta.

Perumpamaan ini dijelaskan oleh J.J Nielsen bahwa : "Seorang yang berpergian ke luar negeri, yang memanggil hamba-hambanya dan mempercayakan (Yunani: paredoken) hartanya kepada mereka. Siapa yang dimaksud adalah Yesus sendiri, dan hamba-hamba-Nya itu adalah murid- murid-Nya. Harta yang dibagi adalah 'talenta' yakni uang logam bernilai besar. Hamba yang pertama diberi 5 (lima), yang seorang lain lagi 2 (dua), dan seorang lain lagi 1 (satu), masingmasing menurut kesanggupannya (Yunani : dunanim)". 19

Para hamba yang telah menerima talenta itu mengembangkannya, yang pertama membawa laba lima (5), yang kedua membawa laba dua (2) sedangkan yang ketiga (3) menyimpan dan tidak membawa laba apa-apa (Matius 25:18). Mereka yang telah mengembangkan talenta yaitu uang tuannya itu, mendapat pujian atau reward dari tuannya setelah pulang daru luar negeri dengan berkata: "baik sekali perbuatanmu itu (Yunani: êvv). Dan ia menyebut hamba yang baik dan setia (Yunani: agathe kai piste, bnd. Matius 24: 45) karena perbuatannya itu, yakni setia dalam perkara kecil (Yunani: oliga). Dia yang modal sebesar lima 
talenta, diberikan "tanggungjawab dalam perkara yang besar, ia malah boleh masuk dan turut kedalam kebahagaiaan (pesta) tuannya"20.

Dari prespektif Injil ini, terlihat bahwa standar tanggung jawab diukur dengan kebaikan dan kesetiaan mengerjakan sesuatu. Ternyata efek dari tanggungjawab yang baik dan setia itu mendapat reward dan pujian dari tuannya, bahkan diberikan tanggung jawab yang lebih besar lagi. Oleh sebab itu ketika seseorang mengerjakan pekerjaan dengan baik dan setia, pekerjaan sekecil apapun itu, maka akan dipercayakan kepadanya tanggung jawab ke level yang lebih besar atau lebih tinggi tinggi. Ada dua kata yang diungkapkan yaitu mengerjakan dengan baik adalah berbicara pada kualitas mutu hasil kerja. Kemudian mengerjakan dengan setia adalah menunjukan kesungguhan dan ketekunan sebagai bagian ketulusan dan keikhlasan.

\section{Injil dan Keteladanan}

Dalam Injil Sinoptis dijumpai keteladanan Yesus pada tataran filisofis dan aplikatifnya, yang dapat diperankan oleh manusia dalam fungsinya sebagai individu, anggota keluarga, komunitas, karyawan, pemimpin organisani, warga Negara maupun sebagai umat Tuhan. Yesus selalu memberi keteladanan dalam segala hal. Salah satu keteladanan yang dicontohkan oleh Yesus dan dapat dijadikan sebagai standar gaya hidup (life style) adalah pernyataan-Nya dalam Markus 10: 45 yang berbunyi "Karena Anak Manusia juga datang bukan untuk dilayani, melainkan untuk melayani dan untuk memberikan nyawa-Nya menjadi tebusan bagi banyak orang”. Demikian juga dalam Matius 20: 28; sama seperti Anak Manusia datang bukan untuk dilayani, melainkan untuk melayani dan untuk memberikan nyawa-Nya menjadi tebusan bagi banyak orang; (just as the Son of Man did not come to be served, but to serve, and to give His life a ransom for

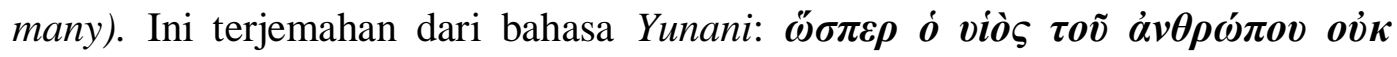

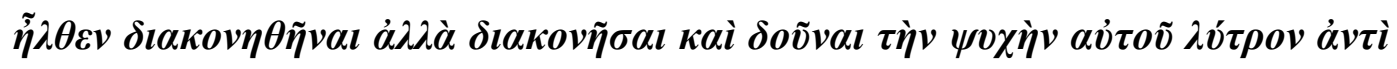
$\pi 0 \lambda \lambda \tilde{\omega} v$.

Diyakini bahwa Yesus Kristus adalah penjelmaan Allah semesta alam, Tuhan Yang Maha Esa, yang telah menjadi manusia, hadir di tengah-tengah 
dunia. Kedudukan-Nya yang sangat mulia tidak menjadi hambatan bagi-Nya untuk melayani umat-Nya. Puncak dari pelayanan-Nya adalah dengan menyerahkan nyawa-Nya sebagai tebusan dosa umat manusia di atas kayu salib. Kehadiran-Nya adalah memberi keteladanan bukan untuk dilayani melainkan untuk melayani.

Tentu tidak mudah mengikuti keteladanan yang dicontohkan Yesus, membutuhkan komitmen yang tinggi untuk berubah ke arah yang dikehendakiNya, sehingga para pengikut-Nya menjadi pelayan yang sunggu- sungguh. Andar Ismael berkomentar tentang gaya hidup dengan mengatakan: "sungguh janggal jika kita berjalan di belakang Yesus namun gaya hidup kita sama saja seperti semula". ${ }^{21}$ Artinya tidak ada perubahan, seharusnya orang Kisten yang telah percaya kepada Yesus, kelihatan pada kehidupannya bahwa dia adalah pengikut Yesus Kristus Kristus yang penuh keteladanan pada perkataan dan perbuatan.

\section{Hasil}

Dari 5 (lima) nilai-nilai budaya Kerja Kementerian Agama, diharapkan seluruh pegawai Kementerian Agama memiliki integitas yang terlihat pada indikandor : hidup jujur, tulus dan ikhlas dalam melayani masyarakat. Ternyata di dalam kitab Injil Sinoptik ditemukan integritas, di mana Yesus Kristus yang diyakini umat Kristen sebagai Tuhan dan Juruselamat dunia, dan pernah hidup di dunia ini, dan dari kehidupan Yesus telah menunjukan kejujuran. Hal itu telihat pada isi ajaran-Nya pada khotbah di Bukit, antara lain pada Matius 5 :37, yang mengajarkan kepada seluruh pendengar-Nya dulu dan sampai sekarang masih berlaku bahwa : 'Jika ya, hendaklah kamu katakan: ya, dan jika tidak, hendaklah kamu katakan tidak. Apa yang lebih daripada itu berasal dari si jahat'. Artinya kejujuran Yesus selama hidup-Nya mengutamakan dan mengajarkan kejujuran. Salah satu ajaran integritas dari Yesus adalah kejuran dan keikhlasan membayar pajak kepada Kaisar (Markus 12 :14). Para penafsir menjelaskan bahwa Yesus juga mengajarkan supaya para pengikut-Nya tidak hanya mengutamakan kecerdasan mempersiapkan masa depan yang terkadang prosesnya tidak benar, tetapi sebagai orang Kristen harus mengutamakan kejujuran dalam segala hal. 
Dalam kitab Injil Sinoptik ditemukan bahwa Yesus mengajarkan Simon Petrus yang memiliki latar belakang seorang nelayan profesional, yang kemudian menjadi murid-Nya untuk tidak hanya mengandalkan kemampuan profesionalnya. Karena terkadang keahlian yang dimiliki dapat mengurangi keyakinan kepada kemahakuasaan Tuhan. Dengan kata lain Yesus hendak mengatakan walaupun seperangkat keahlian telah dimiliki, maka sebagai manusia harus rendah hati, mengutamakan dan mengandalkan Tuhan dalam seluruh kehidupannya. Sebab pengetahuan dan keberhasilan bersumber dari Tuhan.

Kemudian masalah inovasi atau cara berpikir manusia yang selalu ingin kemajuan dan pembaharuan dengan berbagai usaha, penuh perjuangan untuk mencapai cita-cita, pantang menyerah pada keadaan. Kitab Injil Sinoptik memberitakan bahwa seorang perempuan kafir yang berjuang dengan penuh kerendahan hati untuk mendapatkan kesembuhan anaknya yang dirasuk setan (Matius 15 : 21-28). Sekalipun perempuan kafir itu dilarang oleh para murid Yesus, dan bahkan Yesus sendiri mengelak dengan berbagai argumentasi untuk menolak permintaan perempuan itu, namun dia dengan berbagai cara dan tidak kasar mendekati Yesus supaya anaknya sembuh. Akhirnya Yesus memuji kehebatan upayanya, dimana Yesus mengatakan bahwa tidak ada ditemukan di antara umat Israel iman yang inovatif dari perempuan itu. Namun inovasi yang baik adalah yang tidak merugikan atau merusak diri sendiri dan dan orang lain.

Kemudian dalam Kitab Injil Matius 25 :21-28, ditemukan bahwa para hamba yang baik dan setia telah melakukan tanggungjawabnya dengan baik, di mana mereka telah berusaha mengembangkan harta tuannya yang pergi keluarnegeri itu dengan memperoleh laba, walaupun terdapat satu orang yang tidak menjalankan bertanggungjawab dengan baik artinya telah menunjukan kualitas mutu hasil kerja. Selain itu dalam bekerja tidak cukup hanya sebagai pewai yang baik tetapi harus setia artinya menunjukan kesungguhan dan ketekunan. Kitab Injil menceritakan bahwa hamba yang setia dan baik itu mendapat pujian dan promosi dari majikannya ke level yang lebih tinggi karena dia telah setia pada hal- hal yang kecil, maka dipercayakan kepadanya perkara yang lebih besar. 
Nilai budaya kerja Kementerian Agama yang ke lima adalah, keteladanan. Dalam Kitab Injil Matius 20:28 dan Markus 10 : 42, Tuhan Yesus mengatakan: Dia datang kedunia bukan untuk dilayani melainkan untuk melayani. Keteladanan Yesus sangat terbukti sejak kelahiran-Nya sampai menyerahkan diri-Nya mati di Kayu Salib adalah keteladanan yang bermuatan pelayanan bagi uma manusia.

Maka jika diteliti dengan seksama nilai-nilai budaya kerja sebagaimana yang dilaksanakan di Kementerian Agama, ternyata nilai-nilai budaya tersebut sudah dilakukan dan diajarkan oleh Yesus kepada para pengikut-Nya sebagaimana yang diberitakan dalam Injil Sinoptik. Maka seharusnya umat Kristiani dilingkungan Kementerian Agama menjadi pelopor dalam melaksanakan lima nilai budaya kerja dimaksud pada satuan kerja masing-masing, jika mereka telah mempelajari dalam Injil.

\section{Penutup}

Kementerian Agama diharapkan menjadi institusi pelopor dan contoh, model yang melayani masyarakat dengan mengutamakan kepuasan pelanggan. Harapan itu tentu dapat dicapai jika seluruh aparatur Kementerian Agama memiliki tekad yang utuh untuk meningkatkan kinerja dengan berpedoman pada 5 budaya kerja yakni : integritas, profesionalitas, inovatif, tanggungjawab, dan

\section{keteladanan.}

Direktur Jenderal Bimas Kristen sebagai salah satu Satuan Kerja Kementerian Agama, memiliki sejumlah unit kerja sebagai binaannya, diantaranya Sekolah Tinggi Agama Kristen Protestan Negeri. Maka dalam melakukan tugasnya seharusnya berpedoman dari 5 (lima) nilai budaya kerja Kementerian Agama. Bimas Kristen dengan sejumlah unit kerjanya dapat lebih cepat memahami dan mudah untuk mengaplikasikan nilai-nilai budaya dimaksud, karena jauh sebelum ada teori nilai budaya kerja itu sendiri, Tuhan Yesus telah mengajarkan kejujuran, mengawali kegiatan dengan perencanaan yang matang, berusaha bekerja dengan penuh pengharapan, tidak putus asa sekalipun banyak hambatan, mengandalkan Kuasa Tuhan dalam segala hal. Tuhan Yesus juga telah 
mengajarkan setiap orang harus bertanggungjawab dari semua perbuatannya. Tanggungjawab bukan hanya kepada manusia tetapi juga kepada Tuhan baik pada masa sekarang maupun pada masa yang akan datang.Tuhan Yesus telah mengajarkan keteladanan yang dijadikan sebagai gaya hidup (life style) yang ditandai dengan panggilan untuk melayani dan bukan untuk dilayani.

Jika diamati bahwa Yesus bukan hanya ber-retorika dan mengajarkan sejumlah pedoman hidup, melainkan Yesus melakukan segala yang diajarkanNya. Karena itu perkataan dan perbuatan menyatu dalam kehidupan-Nya. Sebagai contoh keteladan yang diajarkan-Nya adalah melayani bukan dilayani. Pelayanan Yesus, terlihat klimaksnya di atas Kayu Salib dengan menyerahkan hidup-Nya sebagai tebusan dosa umat manusia.

\section{Endnote :}

\footnotetext{
${ }^{1}$ Dirjen Bimas Kristen Kemenag RI, Oditta Hutabarat, pidato bimbingan pada wisuda STAKPN Tarutung 16 Maret 2016

${ }^{2}$ Zein, Badudu, 1996, Kamus Umum Bahasa Indonesia, Pustaka Sinar Harapan, Jakarta, h. 535.

${ }^{3}$ Inspektorat Jenderal Kementerian Agama, Rencana Kinerja Tahun 2008, Jakarta, h. 49

${ }^{4}$ Ibelala Gea, Tanggung jawab dosen sebagai Administrator dalam rangka peningkatan kualitas perguruan tinggi, Jurnal Ilmiah Tangkoleh Putai, STAKPN Ambon, Vol. XI. No. 3/Desember 2014. h. 53

${ }^{5}$ Badudu Zein, op. Cit, h. 534

${ }^{6}$ IB. Gea, Pembimbing dan Pengetahuan Alkitab Perjanjian Baru I dan II bagi Perguruan Tinggi Teologi, STAKPN Tarutung 2007.

${ }^{7}$ Kamus Alkitab, 2008, Lembaga Alkitab Indonesia (LAI),Jakarta. h. 344

${ }^{8}$ Ensklopedi Alkitab masa kini, Jilid I, Yayasan Komunikasi Bina Kasih/OMF, Cetakan ke 6, 2005, h. 435

${ }^{9}$ Ensklopedi Alkitab Praktis, LLB, 1978, h. 42

${ }^{10}$ K. Adi Gunawan, Kamus Lengkap Inggris-Indonesia, Indonesia-Inggris, cetakan XIII Maret 2008, penerbit Kartika-Surabaya, h. 191.

${ }^{11}$ Perjanjian Baru: Indonesia:Yunani, 1994, LAI, h.30

${ }^{12}$ Tafsiran Alkitab Masa Kini, 1996, Yayasan Komunikasi Bina Kasih, h. 74

${ }^{13}$ Stephen L. Carter, Integritas, 1999, Pustaka Sinar Harapan Jakarta, h.26

${ }^{14}$ B.J. Baland, P.S. Naipospos, Tafsiran Alkitab Injil Lukas, 1990, BPK Gunung Mulia Jakarta, h. 386.

${ }^{15}$ William Barclay, Pemahaman Alkitab sehari-hari. Injil Lukas, 2009, BPK Gunung Mulia Jakarta, h. 305

${ }^{16}$ Tafsiran Alkitab Masa Kini, 1996, Yayasan Komunikasi Bina Kasih, Jakarta, h. 203.

17 Joko Widodo, Membangun Birokrasi Berbasis Kinerja, 2005, Bayumedia- publishing, Jatim, h. 45-46

${ }^{18}$ J.J de Heer, Tafsiran alkitab Injil Matius Pasal 1-22, Cetakan ke- II, 2011, BPK Gunung Mulia Jakarta, h. 306.

${ }^{19}$ J.J Nielsen, Tafsiran Alkitab Kitab Injil Matius 23- 28; 2010, BPK. Gunung Mulia Jakarta, h 66

20 J.J Nielsen, Tafsiran Alkitab Kitab Injil Matius, ..., h. 67- 68

${ }^{21}$ Andar Ismael, Selamat Mengikuti Dia, 1994, BPK Gunung Mulia, Jakarta, h. 36
} 


\section{DAFTAR PUSTAKA}

Adi Gunawan, K, 2008 . Kamus Lengkap Inggris-Indonesia, Indonesia-Inggris, cetakan XIII Maret 2008, Surabaya, Penerbit Kartika

ALKITAB: 2012 Lembaga Alkitab Indonesia, Jakarta

Badudu, Zain, 1996. Kamus Umum Bahasa Indonesia, Jakarta, Pustaka Sinar Harapan

Baland B.J., \& P.S. Naipospos, 1990. Tafsiran Alkitab Injil Lukas, Jakarta, BPK Gunung Mulia

Barclay, William, 2009. Pemahaman Alkitab Sehari-Hari Injil Lukas, Jakarta, BPK Gunung Mulia

Carter, Stephen L. 1999. Integritas, Jakarta, Pustaka Sinar Harapan

Ensklopedi Alkitab Masa Kini, Jilid I, Yayasan Komunikasi Bina Kasih/OMF, Cetakan ke 6, 2005

Ensklopedi Alkitab Praktis, LLB, 1978

Gea, Ibelala, 2007. Pembimbing dan Pengetahuan Alkitab Perjanjian Baru I dan II bagi Perguruan Tinggi Teologi, STAKPN Tarutung 2007

Gea, Ibelala, 2014. Tanggung Jawab Dosen Sebagai Administrator Dalam Rangka Peningkatan Kualitas Perguruan Tinggi, Jurnal Ilmiah Tangkoleh Putai, STAKPN Ambon, Vol. XI. No. 3/Desember 2014

Heer, J.J de, 2011. Tafsiran Alkitab Injil Matius Pasal 1-22, Cetakan ke- II, Jakarta, BPK Gunung Mulia.

Hutabarat, Oditta, 2016. Pidato Bimbingan Pada Wisuda STAKPN Tarutung 16 Maret 2016, Dirjen Bimas Kristen Kemenag RI

Inspektorat Jenderal Kementerian Agama, Rencana Kinerja Tahun 2008, Jakarta Ismael, Andar, 1994. Selamat Mengikuti Dia, Jakarta, BPK Gunung Mulia Kamus Alkitab, 2008, Lembaga Alkitab Indonesia (LAI), Jakarta

Nielsen, J.J, 2010. Tafsiran Alkitab Kitab Injil Matius 23- 28, Jakarta, BPK. Gunung Mulia

Perjanjian Baru: Indonesia:Yunani, 1994, Jakarta, Lembaga Alkitab Indonesia.

Tafsiran Alkitab Masa Kini, 1996, Jakarta, Yayasan Komunikasi Bina Kasih Tafsiran Alkitab Masa Kini, 1996, Jakarta,Yayasan Komunikasi Bina Kasih

Widodo, Joko, 2005. Membangun Birokrasi Berbasis Kinerja, Jatim, BayumediaPublishing 